\title{
Paleoparasitology at "Place d'Armes", Namur, Belgium: a biostatistics analysis of trichurid eggs between the Old and New World
}

\author{
Paleoparasitologia na "Praça das Armas", Namur, Bélgica: uma análise bioestatística \\ de ovos de tricurídeos entre o Velho e o Novo Mundo \\ Gino Chaves da Rocha ${ }^{1 *}$; Nicolau Maués Serra-Freire ${ }^{2}$ \\ ${ }^{1}$ Programa de Pós Graduação em Saúde Coletiva, Universidade do Planalto Catarinense - UNIPLAC \\ ${ }^{2}$ Laboratório de Ixodides, Referência Nacional para Vetores de Riquétsias, Departamento de Entomologia, Instituto Oswaldo Cruz - FIOCRUZ
}

Received November 5, 2008

Accepted January 15, 2009

\begin{abstract}
Paleoparasitological findings about human occupation and their domestic animals, from Gallo-Roman period up to recent times, were described at the archaeological site of "Place d'Armes", Namur, Belgium, by preventive archaeological excavations. Organic sediment samples from cesspools, latrines and structures-like were analyzed and revealed intestinal parasite eggs (helminthes) in all of the different archaeological contexts. The parasitic association Ascaris sp. and Trichuris sp. was found although it is not easy to determinate the specific parasite species. Trichurids were described in both New and Old Worlds since the prehistorical time. To elucidate the zoological origin of the organic remains, the parasites and the prior function of the sanitary structures Trichuris eggs were statistically analyzed for morphometric parameters, and suggest that it could be an important tool to help the whole paleoparasitological diagnosis.
\end{abstract}

Keywords: Paleoparasitology, Trichuris sp., ancient helmintic diseases, eggs.

\section{Resumo}

Achados paleoparasitológicos sobre a ocupação humana e seus animais domésticos, desde o período Galo-Romano até períodos recentes, foram registrados no sitio arqueológico da "Praça das Armas", em Namur, Bélgica, através de excavaçóes de salvamento arqueológico. Amostras de sedimentos orgânicos coletados de fossas, latrinas e estruturas semelhantes foram analisadas e revelaram ovos de helmintos intestinais, em todos os diferentes contextos arqueológicos. A associação parasitária Ascaris sp. e Trichuris sp. foi encontrada, sem identificação de espécie. Tricurídeos foram descritos em ambos, Novo e Velho Mundo, desde tempos pré-históricos. Para contribuir na elucidação da origem zoological dos vestígios orgânicos, dos parasitos e a função primárias das estruturas sanitárias, ovos de Trichuris foram analisados estatisticamente através dos seus parâmetros morfométricos, e sugerem que esta pode ser uma importante ferramenta para o diagnóstico paleoparasitológico.

Palavras-chave: Paleoparasitologia, Trichuris sp., helmintoses do passado, ovos.

The paleoparasitological inferences allow understanding the existence, the introduction and dispersion of parasites and its infections throughout the ancient human and animal populations. The goal is to establish the evolution and behavior of parasitic diseases over time (ALLISON et al., 1974; ARAÚJO; FERREIRA, 1997; ARAÚJO et al., 2003a). Thus, human migratory routes, inter population contacts, transhumance, predation of wild animals, exploitation of animal resources, relationship and animal

\footnotetext{
*Corresponding author: Gino Chaves da Rocha Programa de Pós Graduaçáo em Saúde Coletiva, Universidade do Planalto Catarinense - UNIPLAC, Av. Castelo Branco, 170, Universitário, CEP 88509-900 Lages - SC, Brasil, Tel.(Fax): +55 21 2560-8217; e-mail: ginorocha@uniplac.net Supported by: CNPq and CAPES/COFECUB
}

domestication are considered since prehistoric times using a paleoparasitological approach. Parasites and its biological forms can be found in all sorts of archaeological organic material (PIKE, 1967; FERREIRA et al., 1987, 1988; BOUCHET et al., 2003a). In this sense, one can consider parasites as biological markers. Their presence, in some archaeological contexts, could indicate that there was a kind of parasitic association, specific or not, as a direct product of an interaction between humans and the environment and even with animals, as an ecological dynamic relation (ARAÚJO; FERREIRA, 1997; ARAÚJO et al., 2003b; ROCHA, 2003; BOUCHET et al., 2003a).

Human occupation, from Gallo-Roman period ( $2^{\text {nd }}$ and $3^{\text {rd }}$ centuries), the Middle Ages up to recent times (19 ${ }^{\text {th }}$ century), across seven historical strata, was recorded in 
the archaeological site of "Place d'Armes", Namur, Belgium, by preventive archaeological excavations (PLUMIER; MEES; VANMECHELEN, 1997). Organic sediment samples from cesspools, latrines and structures-like were analyzed and revealed intestinal parasite eggs (helminthes) in all the different archaeological contexts. To identify the zoological origin of the organic remains and parasites, whether they belonged to humans or other animals, the results were compared with the archaeologists' suppositions, more specifically to understand how those structures were utilized. Thus, archaeological and paleoparasitological approaches are associated to recreate behaviors and health conditions of the settlement over time (ROCHA, 2003; ROCHA et al., 2006). From the archaeological complex of the Place d'Armes settlement, this study drew paleoparasitological inferences, using a statistical approach, to compare egg measurements between the Old and New World trichurids.

Thirty-four sediment samples were collected from the archaeological structures of the Place d'Armes site, comprising

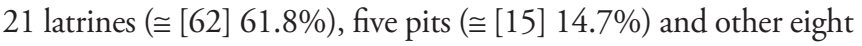

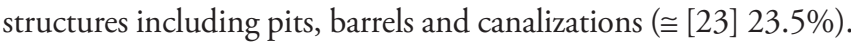
The samples were processed according to Bouchet et al. (1999) protocol. This procedure made possible to separate hard concretions that were attached to the helminth eggs in the sediments.

Identification criteria of helminth eggs were based on size, shape, characteristics of the eggshell ornamentation, the presence or not of the operculum and polar plugs (ROCHA, 2003; ROCHA et al., 2006). Of a total of 16 samples with high concentration of trichurid eggs (over 50 eggs per slide) seven were randomly selected for statistical analysis (Table 1) to differentiate and establish the probable zoological origin of the organic sediment. Twenty slides of each sample were analyzed following standard procedures (ARAÚJO et al., 1998). Only well-preserved eggs (intact egg shape and shell) of Trichuris sp. were measured in their minor (width) and major (length, polar plug to polar plug) diameters. A micrometric scale was used, under optical microscopy, utilizing an Olympus micronal device.

The following statistics were estimated: mean, median, mode, standard deviation, variance and variance/mean relationship to identify the sample distribution type. The Rojas formula (ROJAS, 1964) (Equation 1) was applied to estimate the sample size as:

$$
\mathrm{N}=\frac{\left[\left(\frac{1}{\mathrm{k}}\right)+\left(\frac{1}{\mathrm{M}}\right)\right]}{\mathrm{D}^{2}}
$$

where: $\mathrm{k}$ = aggregation coefficient; $\mathrm{M}$ = mean of trichurid eggs; $\mathrm{D}=$ percentile of variation arbitrated by the researcher. In this case $10 \%$ or $0.1 ; \mathrm{N}=$ number of eggs for estimate or sample size.

The morphometric measurements were compared with the mean value of Confalonieri whipworm population using the one-sample t-test (SERRA-FREIRE, 2002). Considering the standard Confalonieri (1983) the following null hypothesis was formulated: " $\mathrm{H}_{0}$ " - means of major and minor diameters of Namur trichurid eggs are not different from diameter means of trichurid eggs of the population studied by Confalonieri (1983) considering a $10 \%$ significance level.
The paleoparasitological findings are presented in Table 1 that describes archaeological structures, their respective sediment samples, the historical periods and parasite findings at "Place d'Armes" site.

The morphometric analysis of trichurid eggs showed values ranging in width (23.31 to $29.97 \mu \mathrm{m})$ and lenght (46.62 to $59.94 \mu \mathrm{m})$, as showed in Table 2 . The values found by Confalonieri (1983) are present in the same table for comparison.

All measurements had variance/mean relationship values lower than one $(<1)$ indicating that data are randomly distributed around the mean. Thus, it is considered as a normal distribution and the type of kurtosis (based on the size of distribution tails) is leptokurtic (large tails). The sample size estimated, according to Rojas (1964), indicated that all samples studied could be smaller than previously arbitrated.

\section{About trichurid samples}

Sample 02.007 and 02.169- The $t$-test is statistically significant for both minor and major diameters, (" $\mathrm{t}$ " calc $=0.84$ and 0.61 , respectively, Sample 02.007; "t" calc $=2.73$ Sample 02.169) meaning that trichurids are not different from Confalonieri population.

Sample 04.443 and 04.424 - The result of the $t$-test is statistically significant (" $\mathrm{t}$ " calc $=4.38$ and 2,96, respectively) for the minor diameter, but not statistically significant (" $\mathrm{t}$ " calc $=0.32$ and 0,83 , respectively) for the major diameter. In this situation, where at least one mean diameter differs significantly, the final conclusion is that the sample does not belong to T. trichiura species.

Sample 04.453 and 04.269- The $t$-test is statistically significant (" $\mathrm{t}$ " calc $=3.99$ ) for the minor diameter so these eggs do not belong to T. trichiura species. Sample $\mathbf{0 4 . 0 1 1}$ - The $t$-test is also statistically significant (" $\mathrm{t}$ " calc $=3.05$ ) for the minor diameter. The fact that there is at least one significant difference in a diameter is sufficient to reject the null hypothesis and it can be concluded that these Trichuris eggs do not belong to Confalonieri population.

\section{About sedimentation techniques}

Many techniques to concentrate and recover helminth eggs from latrines and sanitary deposits have been reviewed, presented and discussed (BOUCHET et al., 2003b). As discussed by Fugassa, Araújo e Guichón (2006), they had tested and compared three techniques for the extraction of parasite eggs from archaeological sediments. It seems right when the egg's concentration can be estimated by a controlled essay or in cases when sediment samples can be collected from a known skeleton region (FERREIRA; ARAÚJO; CONFALONIERI, 1983). Otherwise, it is not the same when inferences about parasitic findings have to be made from sediments collected in a varied sort of sanitary deposits like latrines, cesspools, pits, barrels and structures-like (REINHARD et al., 1988). It means that there are not objective references to infer about the origin of fecal matter. In these deposits there was not any clear evidence of human skeleton or coprolites. Such technical details promote a valuable exchange of ideas and help improving the techniques. The paleoparasitological contexts are so different and so similar at the same time. 


\section{About the statistical basis for analysis}

It is important to make some considerations. First, the significance level previously set at $10 \%$, taking the degrees of freedom $(\mathrm{df})$ to samples $(\mathrm{df}=\mathrm{n}-1)$ into account was due to lack of previous studies that could justify the security level reduction of the inferences made. Second, Rojas formula was used to estimate sample sizes by calculating the parasitic aggregation coefficient in the soil (ROJAS, 1964). In his study the analysis was also extended to the concentration of helminth eggs in animal feces samples. Thus, the same principle was applied to the sediments collected at "Place d'Armes" archaeological site. In fact, there is a possibility that helminth eggs are distributed across a considerable stratigraphic level. Based on Rojas results, the parasitic aggregation coefficient indicated that the sample sizes were adequate to infer about parasitic findings.

Table 1. Description of archaeological structures, their respective sediment samples, the historical periods and parasite findings at "Place d'Armes" site, Namur, Belgium.

\begin{tabular}{cc}
\hline Structures & $\begin{array}{c}\text { Samples and paleoparasitological } \\
\text { findings }\end{array}$ \\
\hline
\end{tabular}

Carolingean Period. $9^{\text {th }}-11^{\text {th }}$ (1055 A.D.) Centuries

(Z02 F5) Pit-silo $\quad$ Capillaria sp.

$11^{\text {th }}$ (1055 A.D.)-12 ${ }^{\text {th }}(1100$ A.D.) Centuries

(Z04 F85) Latrine 04.443: Ascaris sp.; Trichuris sp;

Fasciola hepatica; Taenia sp.

(Z04 F106) Latrine 04.424: Ascaris sp.; Trichuris sp.;

Diphyllobothrium sp.

$14^{\text {th }}-15^{\text {th }}$ Centuries

(Z02 F1) Latrine 02.007: Ascaris sp.; Trichuris sp.

(Z04 F56) Barrel 04.453: Ascaris sp.; Trichuris sp.

(Z04 F1) Barrel 04.011: Ascaris sp.; Trichuris sp.;

Diphyllobothrium sp.; Oxyuris equi

The Renaissance: $15^{\text {th }}-17^{\text {th }}(1618$ A.D.) Centuries

(Z04 F60) Latrine 04.269: Ascaris sp.; Trichuris sp.; Taenia sp.
The criterion to reject the null hypothesis was that one mean (either minor or major diameter) should be significantly different from those means of Confalonieri trichurid population. In his experimental study, Confalonieri (1983) concluded that morphological changes, as a result of fecal desiccation in archaeological sediments, do not preclude the generic diagnosis of Trichuris sp. or even the differential diagnosis between species. Some significant and non-significant statistically differences of morphometric parameters could indicate the likelihood over time of taphonomic alterations as discussed by Bouchet (1995b); Bouchet et al. (1999), Ubelaker et al. (2002), and Rocha et al. (2006). We also believe that morphometric parameters of the eggs could indicate another species of Trichuris sp. (ROCHA et al., 2006).

\section{About the archaeological contexts, paleoparasitological findings and statistical inferences}

The statistical inferences presented here were then compared with the archaeological field description and paleoparasitological diagnosis as described by Rocha (2003) and Rocha et al. (2006). The sample 02.169 was collected from a Carolingean pit-silo $\left(9^{\text {th }}-11^{\text {th }}\right.$ centuries) and the layer to which it belonged was used to stuff the structure. Helminth eggs of Ascaris sp., Trichuris sp. and Capillaria sp. were recovered. These parasitological associations (findings) can be related to any animal host and the statistical inference indicates that trichurid eggs found do not belong to T. trichiura species.

The archaeologists described as latrine the structure in which organic sediment (sample $\mathbf{0 4 . 4 4 3}$ ) was collected $\left(11^{\text {th }}-12^{\text {th }}\right.$ centuries). We found Taenia sp., Ascaris sp., Trichuris sp. and Fasciola hepatica eggs. The statistical inferences indicated that the $t$-test of the major diameter of trichurid eggs could belong to T. trichiura although the $t$-test of the minor diameter rejected the null hypothesis. It is thus considered that the eggs do not belong to a human origin. To corroborate just the opposite Taenia sp. eggs are a human specific parasite. Thus in these cases when taenids are found associated so inferences could be done about the human origin of the fecal

Table 2. Sediment samples, means, standard deviations and range of minor (mDiam) and major diameters (MDiam), in micrometers $(\mu \mathrm{m})$, of trichurid eggs from "Place d'Armes" archaeological site, Namur, Belgium, compared to those of Trichuris trichiura eggs according to Confalonieri (1983) reference.

\begin{tabular}{cccccccc}
\hline \multirow{2}{*}{ Sediment samples } & \multicolumn{2}{c}{ Means } & \multicolumn{2}{c}{ Standard deviation } & \multicolumn{3}{c}{ Range } \\
\cline { 2 - 7 } & mDiam & MDiam & mDiam & MDiam & mDiam & MDiam \\
\hline 02.169 & 26.75 & 52.06 & \pm 0.76 & \pm 2.04 & $24.98-28.31$ & $49.95-56.61$ \\
04.443 & 27.20 & 54.76 & \pm 1.40 & \pm 1.50 & $23.31-29.97$ & $53.28-56.61$ & 15 \\
04.424 & 26.43 & 54.90 & \pm 1.08 & \pm 2.31 & $23.31-28.31$ & $49.95-59.94$ & 43 \\
02.007 & 26.31 & 55.28 & \pm 1.82 & \pm 1.82 & $23.31-28.31$ & $53.28-56.61$ & 05 \\
04.453 & 26.60 & 52.32 & \pm 0.90 & \pm 2.85 & $23.31-28.31$ & $46.62-59.94$ & 45 \\
04.011 & 26.86 & 54.39 & \pm 1.07 & \pm 2.15 & $24.98-29.97$ & $49.95-56.61$ & 15 \\
04.269 & 27.47 & 54.44 & \pm 1.41 & \pm 2.08 & $24.98-29.97$ & $53.28-58.28$ & 10 \\
Confalonieri (1983) & 25.80 & 54.56 & \pm 1.35 & $\pm 2,63$ & $22.75-31.63$ & $44.75-60.25$ \\
\hline
\end{tabular}


matter. The measurements of taenid eggs found were related to human or swine taenids. Paleoparasitological and archaeological evidence is so strong to support the diagnosis of the sanitary structure as of human usefulness. The sample $\mathbf{0 4 . 4 2 4}$ was collected from another latrine of the same period although taenid eggs were not recovered. The statistical inference indicated a non-human origin for the organic matter present in the sediment.

Unlike the previous samples the statistics indicated the human origin of the tricurid eggs found (sample 02.007). Archaeological traces like dog and poultry skeleton and domestic rejection were recorded in the structure described as latrine $\left(14^{\text {th }}-15^{\text {th }}\right.$ centuries). Ascaris sp. and Trichuris sp. eggs were found. Paleoparasitological inferences suggest a new function to the latrine (a garbage dump). The sediment sample $04.453\left(14^{\text {th }}-15^{\text {th }}\right.$ centuries) was recovered from a barrel (commonly used as an urban fosse during this period) and Ascaris sp. and Trichuris sp. eggs were also found. Trichurid egg measurements indicated the human origin of the organic matter although the opposite was found in the statistical analysis. In this case, archaeological, paleoparasitological and statistic data are not consistent. Another sample $\mathbf{0 4 . 0 1 1}$ collected from a barrel showed the classical parasitic association and Diphyllobothrium sp. and Oxyuris equi eggs as well. These eggs indicate human consumption of raw fish and the existence of horses, respectively. Once again there was a statistical inconsistence in the significance of the parameters and the inference tended to reject the null hypothesis. It is very likely, according to the archaeological descriptions, the structure had a function to receive all sorts of human and animal refuse. A latrine from the $15^{\text {th }}$ century, in the stratigraphic level of the sample 04.269, revealed Taenia sp. eggs indicating human fecal matter. Though statistically trichurid eggs do not belong to T. trichiura there is strong archaeological and paleoparasitological evidence.

Some parasite eggs' characteristics allowed to identifying the fecal origin present in the sediments based on the parasitic spectrum (parasitic association) and morphometric comparisons between human and animal intestinal helminthes. While the presence of host-specific intestinal parasite eggs defines the zoological origin of the fecal material, such as Taenia sp. (human specific platyhelminth) or Oxyuris equi (Equidae specific nematode), in some cases it was not possible to identify the parasite species. We should point out that, during the Middle Ages, latrines received all sorts of refuse such as domestic garbage, human excrements and animal remains. Latrines have served as sanitary privies only from the $18^{\text {th }}$ century (ROSEN, 1994; MONESTIER, 1997).

The parasitic association, Ascaris sp. (roundworms) and Trichuris sp. (whipworms), was described across seven historic strata at "Place d'Armes" site (ROCHA, 2003; ROCHA et al. 2006). This duo parasitizes humans and swine. Their eggs are commonly seen in most organic sediments found in archaeological deposits and sites (TAYLOR, 1955; PIKE, 1967; GREIG, 1982; BOUCHET 1995a, b, BOUCHET and PAICHELER, 1995; ASPÖCK et al., 1996; BOUCHET et al. 2003b; FERNANDES et al. 2005). Therefore, the identification of both genera could contribute to elucidate the zoological origin of organic sediments. In regard to morphometric characteristics (measurements), eggs belonging to Ascaris genus are so similar that it is not possible to identify whether the infected hosts were humans or swine, $A$. lumbricoides and $A$. suum, respectively
(LOREILLE; BOUCHET, 2003). However, Trichuris eggs have distinct measurements that allow establishing differential diagnosis between species, such as T. trichiura (human specific) and T. suis (swine specific), (BEER, 1976; CONFALONIERI, 1983; FERREIRA; ARAÚJO; CONFALONIERI, 1988; ROUSSET, 1993).

Trichurid eggs have been found in sediments throughout European archaeological sites since the Neolithic period up to modern times and their well-preserved condition makes it possible to reach an accurate diagnosis. In the New World they were found in human feces (coprolites) in South American archaeological sites, dated as old as 7,200 years (FERREIRA et al., 1987; FERREIRA; ARAUJO; CONFALONIERI, 1983). These findings help answering the questions about the very first human occupation of the American continent, the peopling of the Americas (ARAUJO et al. 1988; FERREIRA; ARAUJO, 1996, REINHARD et al. 2001).

The majority of "Place d'Armes" samples that were statistically analyzed did not belong to human trichurids referred by Confalonieri (1983). These inferences were challenged based on the archaeological contexts and paleoparasitological findings. Statistical inferences can be considered a reliable technique to corroborate helminth paleoparasitological diagnosis.

\section{Acknowledgements}

We would like to thank the scientific support of Dr. Luiz Fernando Ferreira and Dr. Adauto Araújo from the National School of Public Health - Fiocruz, Brazil, and Dr. Françoise Bouchet from the Université de Reims Champagne-Ardenne, France.

\section{References}

ALLISON, M. J. et al. A case of hookworm infection in pre-Columbian American. American Journal of Physycal Anthropology, v. 41, p. 103-106, 1974.

ARAÚJO, A.; FERREIRA, L. F. Homens e parasitos: a contribuição da paleoparasitologia para a questáo da origem do homem na América. Revista USP, v. 34, p. 58-70, 2000.

ARAÚJO, A. et al. Parasitism, the diversity of life, and paleoparasitology. Memórias do Insituto Oswaldo Cruz, v. 98, n. 1, p. 5-11, 2003 a.

ARAÚJO, A. et al. Parasitos, parasitismo e paleoparasitologia molecular. Anais da Academia Nacional de Medicina, v. 160, n. 1, p. 20-27, 2003b.

ARAÚJO, A. et al. Paleoparasitology: perspectives with new techniques. Revista do Instituto de Medicina Tropical de Sáo Paulo, v. 40, n. 6 , p. 371-376, 1998.

ARAÚJO, A.; FERREIRA, L. F.; CONFALONIERI, U. A contribution to the study of helminth findings in archaeological material in Brazil. Revista Brasileira de Biologia, v. 41, n. 4, p. 873-881, 1981.

ARAÚJO, A. et al. Hookworm and the peopling of America. Cadernos de Saúde Pública, v. 4, n. 2, p. 226-233, 1988.

ASPÖCK, H.; AUER, H.; PICHER, O. Parasites and parasitic diseases in prehistoric human populations in Central Europe. Helminthologia, v. 36, n. 3, p. 139-145, 1996. 
BEER, R. J. S. The relationship between Trichuris trichiura (Linnaeus 1758) of man and Trichuris suis (Schrank 1788) of the pig. Research in Veterinary Science, v. 20, p. 47-54, 1976.

BOUCHET, F. La paléoparasitologie au Grand Louvre. Bulletin d' Association des Anciens Eléves de l'Institute Pasteur, v. 143, p. 8-11, 1995.

- Maladies parasitaires identifiées dans le remplissage d'une latrine à tonneau au village déserté de Walraversijde (ville d'Ostende, prov. de Flandre Occidentale). In: PIETERS, M. Een 15de-eeuwse sector van het verdwenen vissersdorp te Raversijde (stad Oostende, prov. WestVlaanderen) Interimverslag 1994. Archeologie in Vlaanderen, v. 4, p. 234-235, 1995.

BOUCHET, F.; PAICHELER, J. C. Paléoparasitologie: présomption d'un cas de bilharziose au XV siècle à Montbéliard (Doubs, France). Sciences de la vie, v. 318, p. 811-814, 1995.

BOUCHET, F. et al. Parasite remains in archaelogical sites. Memórias do Insituto Oswaldo Cruz, v. 98, n. 1, p. 47-52, 2003.

BOUCHET, F.; HARTER, S.; LE BAILLY, M. The State-of-the-Art of paleoparasitological research in the old world. Memórias do Insituto Oswaldo Cruz, v. 98, n. 1, p. 95-01, 2003b.

BOUCHET, F. et al. First Paleoparasitological analysis of a midden in the Aleutian Island (Alaska): results and limits. Journal of Parasitology, v. 85, n. 2, p. 369-372, 1999.

CONFAlONIERI, U. E. C. Paleoparasitologia do gênero Trichuris Roederer, 1761, com um estudo paleoepidemiológico sobre a origem do Trichuris trichiura (Linn, 1771), Stiles, 1901 na América (Nematoda, Trichuridae). Itaguaí, 1983. 170 p. Dissertação (Mestrado em Parasitologia) - Universidade Federal Rural do Rio de Janeiro UFRRJ.

FERNANDES, A. et al. Intestinal parasite analysis in organic sediments collected from 16 century Belgian archeological site. Caderno de Saúde Pública, v. 21, n. 1, p. 329-332, 2005.

FERREIRA, L. F; ARAÚJO, A. On hookworms and transpacific contact. Parasitology Today, v. 12, n. 2, p. 454-454, 1996.

FERREIRA, L. F; ARAÚJO, A.; CONFALONIERI, U. Paleoparasitologia no Brasil. Rio de Janeiro: PEC/ENSP, 1988. 160 p.

FERREIRA, L. F. et al. The finding of hookworm eggs in human coprolites from $7230 \pm 80$ years BP, from Piauí, Brazil. Anais da Academia Brasileira de Ciências, v. 59, p. 280-281, 1987.

FERREIRA, L. F.; ARAÚJO, A.; CONFALONIERI, U. The finding of helminth eggs in a brazilian mummy. Transactions of the Royal Society of Tropical Medicine and Hygiene, v. 77, p. 65-67, 1983.
FUGASSA, M. H.; ARAÚJO, A.; GUICHÓN, R. A. Quantitative paleoparasitology applied to archaeological sediments. Memórias do Instituto Oswaldo Cruz, v. 101, n. 2, p. 29-33, 2006.

GREIG, J. Garderobes, sewers, cesspits and latrines. Current Archaeology, v. 85, p. 49-52, 1982.

LOREILLE, O.; BOUCHET, F. Evolution of Ascariasis in humans and pigs: a multi-disciplinary approach. Memórias do Instituto Oswaldo Cruz, v. 98, n. 1, p. 39-46, 2003.

MONESTIER, M. Histoire et bizarreries sociales des excréments: des origines à nos jours. Paris: Le cherche midi éditeur, 1997.

PIKE, A. W. The recovery of parasite eggs from ancient cesspit and latrine deposits: an approach to the study of early parasite infections. In: BROTHWELL, D.; SANDINSON, A. T. (Ed.). Diseases in antiquity. London: Thomas Springfield, 1967. p. 184-188.

PLUMIER, H. N.; MEES, N.; VANMECHELEN, R. Namur: eléments de topographie urbaine au bas moyen age. In: CORBIAU, M. H. (Coord.). Le patrimoine archéologique de Wallonie. Namur: DGATLP, 1997.

REINHARD, K. J. et al. American hookworm antiquity. Medical Anthropology, v. 20, n. 1, p. 97-101, 2001.

REINHARD, K. J. et al. Recovery of parasite remains from coprolites and latrines: aspects of paleoparasitological technique. Homo, v. 37, p. 217-239, 1988.

ROCHA, G. C. Praça das Armas, Namur, Bélgica. Contribuiçáo de um estudo paleoparasitológico. Rio de Janeiro, 2003. 145 p. Tese (Doutorado em Saúde Pública) - Fundação Oswaldo Cruz - Fiocruz.

ROCHA, G. C. et al. Paleoparasitological remains revealed by seven historic contexts from "Place d'Armes", Namur, Belgium. Memórias do Instituto Oswaldo Cruz, v. 101, n. 2, p. 43-52, 2006.

ROJAS, B. La binomial negativa y la estimación de intensidad de plagas en el suelo. Fitotecnia Latinoamericana, v. 1, n. 1, p. 27-37, 1964.

ROSEN, G. Uma história da saúde pública. São Paulo: UNESP, 1994.

ROUSSET, J. J. Copro-parasitologique pratique: intérêt et méthodologie. Notions sur les parasites du tube digestive. Paris: ESTEM, 1993.

SERRA-FREIRE, N. M. Planejamento e análise de pesquisas parasitológicas. Niterói: EdUFF, 2002.

TAYLOR, E. L. Parasitic helminths in Medieval remains. Veterinary Records, v. 67, p. 218-228, 1955.

UBELAKER, H. et al. The Use of SEM/EDS Analysis to distinguish dental and osseus tissue from other materials. Journal of Forensic Science, v. 47, n. 5, p. 940-943, 2002. 